\title{
OUTLINE OF THE GEOLOGY OF TEPEKÖY AREA, NW KONYA/CENTRAL TURKEY
}

DOI: http://dx.doi.org/10.18509/GBP.2020.09

UDC: $551.7(560)$

\author{
Büşra Eryiğit ${ }^{1}$ \\ Hüseyin Kurt ${ }^{2}$ \\ Kerim Koçak ${ }^{2}$ \\ ${ }^{1}$ Konya Technical University, Graduate Institute, Konya, Turkey \\ ${ }^{2}$ Konya Technical University, Department of Geological Eng., Konya, Turkey
}

\begin{abstract}
It is aimed to outline the geological characteristics of Tepeköy region, in where Upper Permian - Lower Cretaceous Gökçeyurt group is exposed. Upper Permian Derbent formation, oldest formation of the group, is exposed with metacarbonates, quartzite and phyllite, which shows transition laterally and vertically to Upper Permian-Upper Triassic Aladağ formation containing phyllite, metasandstone, metaconglomerate, calcschist and metacarbonate. Upper Triassic-Lower Cretaceous Lorasdağ formation, the youngest one of the group, overly conformably the Aladag formation, and is composed of recrystallized limestone, dolomite and dolomitic limestone. All these units were overlied unconformably by Upper Miocene-Lower Pliocene Dilekçi Group, containing Sille formation, Ulumuhsine formation, Küçükmuhsine formation, Sulutas volcanics and Yürükler formation. The Sille formation is characterized by alluvial material while the Ulumuhsine formation contains lacustrine limestones. Then intensive calc-alkaline volcanic activity initiated, producing tuff, tuffite, volcanic breccia (Küçükmuhsine formation), and various volcanic rocks, mostly dacite, andesite and rare basalt (Sulutas volcanics), which is covered unconformably by Upper Pliocene-Quaternary alluvial sediments
\end{abstract}

Keywords: Stratigraphy, Geology, Tepeköy, Konya

\section{INTRODUCTION}

The study area is located around the town of Tepeköy area, about $46 \mathrm{~km}$ northwest of Konya. It is termed as "Anatolides" [1], the Bolkardağ 1 Unit [2], "Afyon-Bolkardağ 1 zone" [3], "Anatolide-Toride" [4].

\section{GEOLOGICAL SETTING}

Gökçeyurt group represents originally the shelf sequence contains three formations, namely, Upper Permian Derbent formation, Upper Permian - Upper Triyas Aladağ formation and Upper Triassic - Lower Cretaceous Lorasdağ 1 formation, all of which exhibit lateral and vertical transitions to each other [5]. The Gökçeyurt group is represented by low-grade metamorphic rocks, and overlied by cover formations unconformably. It extends from the south of Güneypınar village, through the Kocaçaldağ height to $1.5 \mathrm{~km}$ northeast of Tepeköy.

Derbent Formation has been named first by [6] while referring unit is named as "Eldeş Formation" [7] and as "Derbent Formation" by [5]. This unit observed in the northwest of Tepeköy, is generally grey to black coloured, medium-thick bedded recrystallized 
limestone with abundant fossils, dolomitic limestone, dolomite, phyllite and metaquartzite. The age of the formation is suggested to be Upper Permian based on its fossil content by [5].

The Aladağ Formation has been named first as by [6], and consists of metasandstone, metaconglomerate and metacarbonate. It was named later as "Ardiçli formation [7] and, "Aladağ formation" by [5]. Metacarbonates are observed as pink, cream and grey colors. The metasandstones exhibit some structures such as cross-bedding and grading bedding. The Aladağ formation rests on the Derbent formation, and overlied by Upper Triassic Lower Cretaceous Lorasdağ formation [5]. The age of Aladağ formation is suggested to be Upper Permian-Upper Triassic by [5], and was overlied conformably by Lorasdağ 1 Formation, named by [6] and [7]. The Lorasdağ 1 formation widely observed around Çatal Tepe and Güneyçalbaşı Tepe in the area, including generally grayish, sometimes brownred, and sometimes metachert-interlayered recrystallized limestone, dolomitic limestone and dolomites. It is suggested to be Lias-Early Cretaceous by [6]; Late Jurassic-Late Cretaceous by [8]; Middle Triassic Early Cretaceous by [7]. [5] proposes Late TriassicEarly Cretaceous age for the formation based on its contact relation and fossil content. The Lorasdağ1 Formation is overlied with an angular unconformity by the Upper Miocene-Lower Pliocene Dilekçi group [5], which consists of alluvial fan and lacustrine layers, and rocks with volcanic origin. [6] named unit as "Dilekçi formation" while [5] evaluated it as a group, "Dilekçi group". The group consists of Sille, Ulumuhsine and Küçükmuhsine formations, Sulutas volcanics and Yürükler formation, from bottom to top.

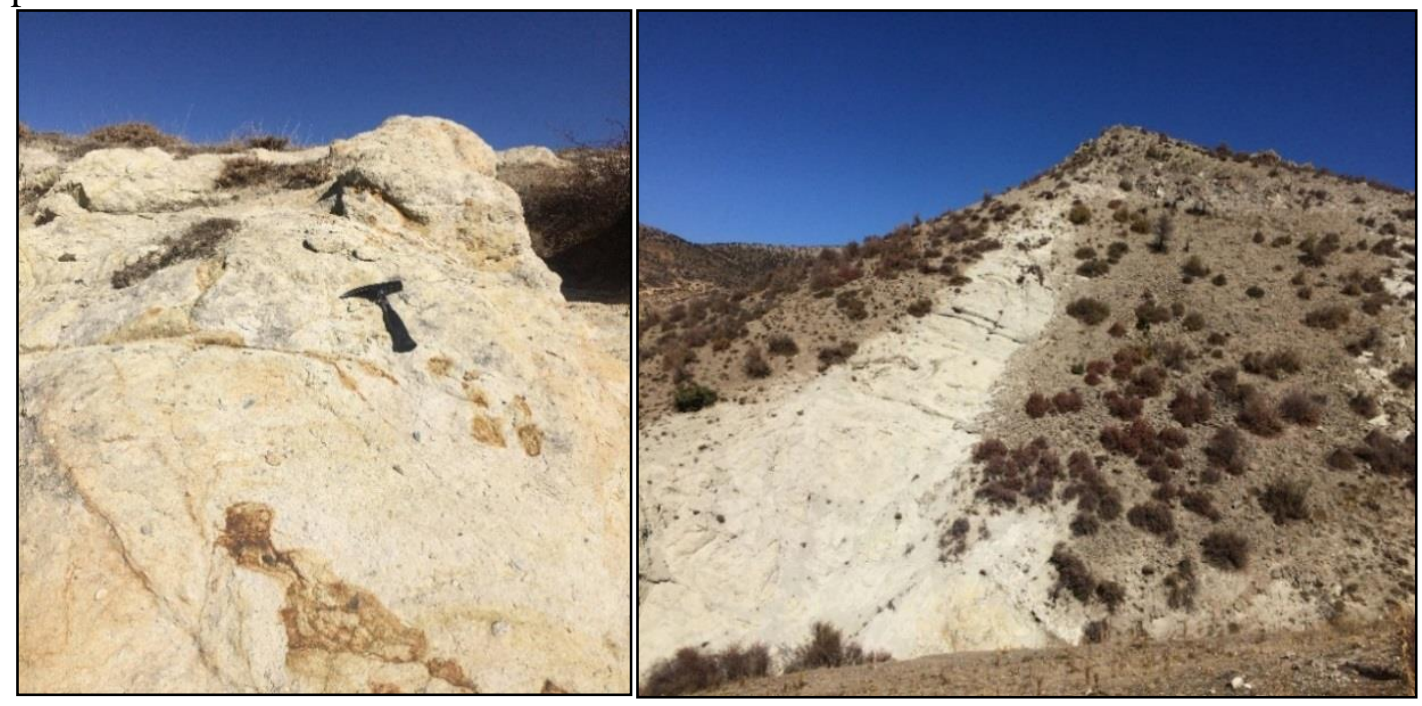

Figure 1: Land view of tuff from Küçükmuhsine formation

The Sille Formation is the lowest unit of the group, and named as "Sille formation" by [5]. It consists of alternation of red-brown, grey conglomerate, sandstone and mud. The poorly sorted conglomerates contain rock angular-semi-angular and sometimes rounded fragments derived from Bozdağ massive, and cemented by sandy and clayish matrix [5]. The formation is suggested to be Pliocene age by [6] based on the fresh water fossils while [5] offered to be Upper Miocene-Lower Pliocene based on radiometric age and contact relations. The Ulumuhsine Formation studied by [6] as an "Ulumuhsine limestone member" while [5] consider it as a formation, "Ulumuhsine formation" in his study. It contains limestone, clayish limestone, mudstone and marl. 
Küçükmuhsine Formation includes alternation of white, grey and pink coloured tuff, tuffite and volcanic breccia volcanogenic sandstone (Figure 1). [5] suggest that the formation passes laterally and vertically Sulutas volcanites. [6] distinguished this unit as "Küçükmuhsine agglomerate member" and "Erenkaya tuff member" within the "Dilekçi formation". However, [5] has adopted it as "Küçükmuhsine formation" due to fact that volcano-sedimentary formations cannot be separated as tuff and agglomerate.

Sulutas Volcanics are observed as volcanic neck, lava flow and block flow in the east and west of the study area (Figure 2). The unit is named as "Sulutas andesite member" within the "Dilekçi formation" by [6] [9] defined as the andesite, dacite, rhyodacite and rhyolite in the regional scale studies while [10] defined as andesite and dacite. Finally, [5] named as the "Sulutas volcanics", which are observed as volcanic neck, lava flow and block flow in the east and west of the study area (Figure 2).

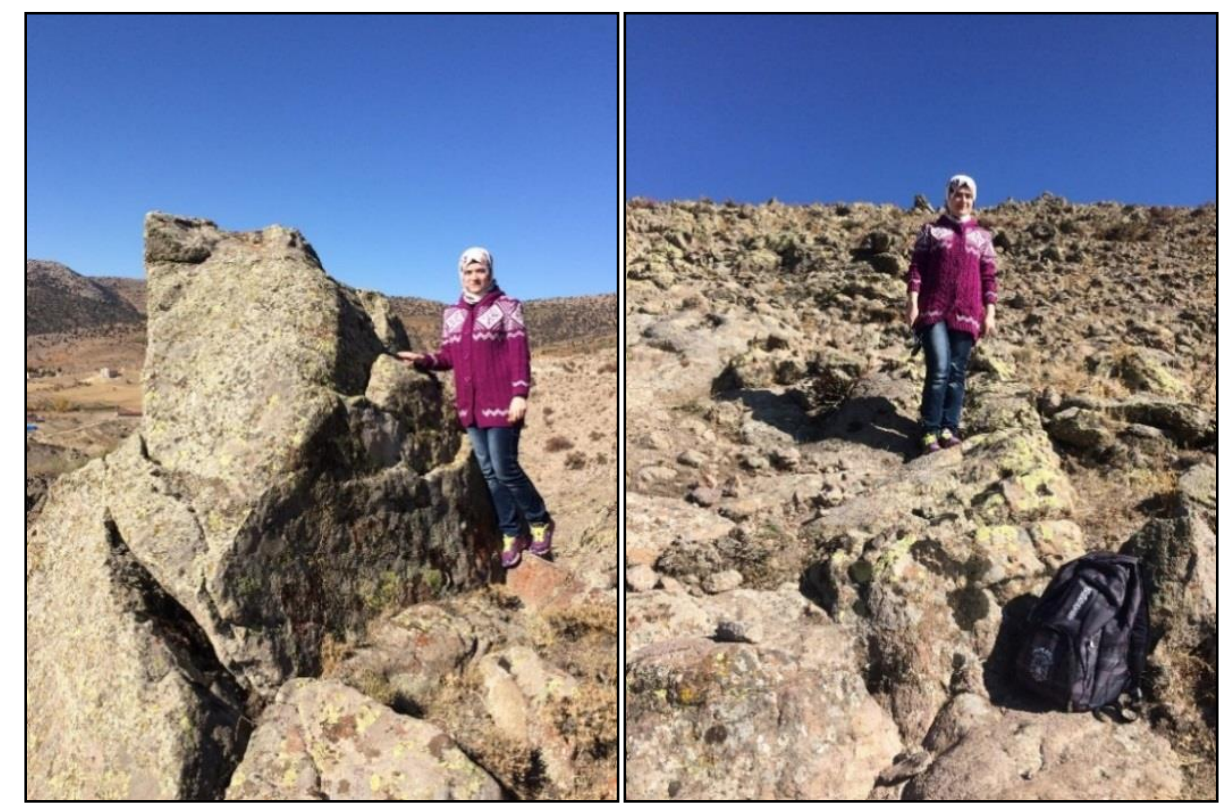

Figure 2: Land view of Sulutas volcanics

Yürükler Formation observed in the south of the study area, includes red, brown and grey conglomerates, mud with sand and gravel, and mud. The gravel of the conglomerate is derived older formations, such as low-grade metamorphic rocks and ophiolitic rocks. It is overlied with an angular unconformity by Toprakl1 Formation, which is composed of red, brown, grey conglomerate, mud and pebbles with subordinate caliche levels. It was named as "Topraklı conglomerate" [11] while [5] named as "Toprakl1 formation". The conglomerate has heterogenic and polygenic character, with gravels derived from older formations. The Toprakl1 formation covers all units with an angular unconformity, and was considered to be Upper Pliocene-Quaternary [5].

\section{RESULTS}

Pre-Neogene units in the study area are represented by metacarbonates, quartzite and phyllite, which pass laterally and vertically to Upper Permian-Upper Triassic Aladağ formation with phyllite, metasandstone, metaconglomerate, calcschist and metacarbonate. Upper Triassic-Lower Cretaceous Lorasdağ 1 formation is represented by recrystallized carbonates. All these units were overlied unconformably by Upper Miocene-Lower Pliocene Dilekçi Group, containing Sille formation (alluvial material), 
Ulumuhsine formation (lacustrine limestones), Küçükmuhsine formation (volcanosedimentary rocks), Sulutas volcanics and Yürükler formation (alluvial sediments).

\section{REFERENCES}

[1] Ketin I. Tectonic units of Anatolia (Asia Minor) (in Turkish), Mineral Res Explor Bull Turk, vol. 66, pp.20-34, 1966.

[2] Ozgul N. Toroslar ' in bazı temel jeoloji özellikleri, TJB, vol. 19, pp.65-78, 1976.

[3] Okay AI. High-pressure/low temperature metamorphic rocks of Turkey., Geol. Soc. Amer. Mem, vol. 164, pp.338-348, 1986.

[4] Okay A, Tüysüz O. Tethyan sutures of northern Turkey. In: Durand B, Jolivet L, Horvárt, Séranne M (eds) The mediterranean basins: tertiary extension within the alpine Orogen, Geological Society London Special Publications, vol. 156, pp.475-515, 1999.

[5] Eren Y. Konya kuzeybatısında Bozdağlar Masifinin otokton ve örtü birimlerinin stratigrafisi (in Turkish), Geol Bull Turk, vol. 36, pp.7-23, 1993.

[6] Göger E, Kiral K. Kizilören dolayinın jeolojisi (1969).

[7] Özcan A; Göncüoğlu MC; Turhan N; Uysal S, Şentürk K. Late Palaeozoic evolution of the Kütahya-Bolkardağ Belt., METU Journal of Pure and Applied Science, vol. 21, pp.211-220, 1988.

[8] Gormus M. (1984). Kızılören (Konya) dolayının jeolojisinin incelemesi. (Master), Selcuk Uni., Konya

[9] Jung D, Keller J. (1972) Die jungen vulkanite im raum zwischen Konya und Kayseri (zentralAnatolien; roches volcaniques jeunes dans la region situee entre Konya et Kayseri, Anatolie centrale.

[10] Ota R, Dinçel A. Volcanic rocks of Turkey, Bull. Geol. Surv. Japon, vol. 26, pp.18 - 45, 1975.

[11] Doğan A. (1975). Sizma-Ladik (Konya) civa sahasının jeolojisi ve maden yatakları sorunlarının incelenmesi. (Master), İstanbul Uni., İstanbul. 